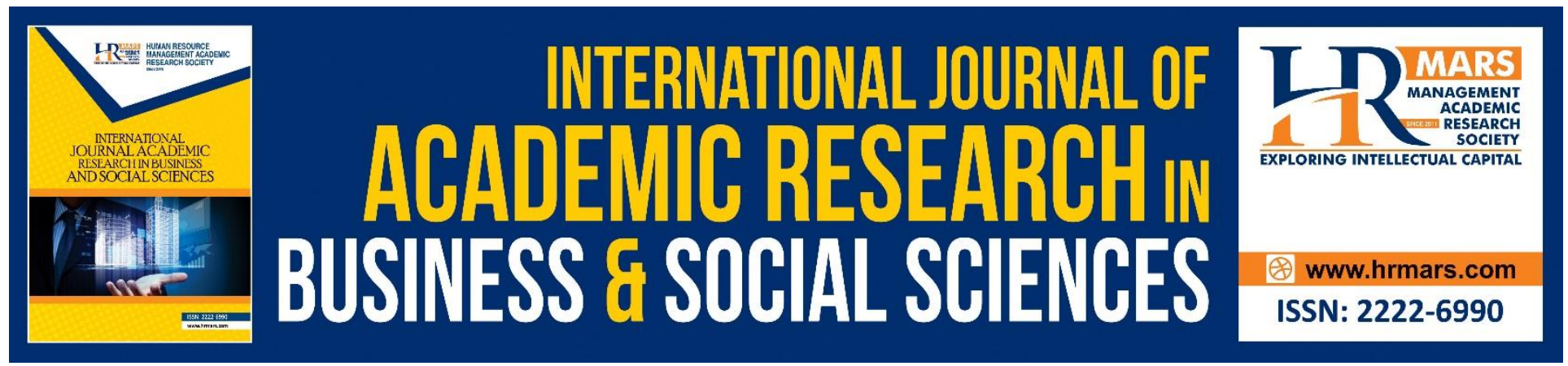

\title{
Smart Diagnostic Test in Remedial Education
}

\author{
Noor Aini Binti Ahmad
}

To Link this Article: http://dx.doi.org/10.6007/IJARBSS/v8-i12/5447

DOI: $10.6007 /$ IJARBSS/v8-i12/5447

Received: 22 Nov 2018, Revised: 13 Dec 2018, Accepted: 21 Dec 2018

Published Online: 04 Jan 2019

In-Text Citation: (Ahmad, 2018)

To Cite this Article: Ahmad, N. A. B. (2018). Smart Diagnostic Test in Remedial Education. International Journal of Academic Research in Business and Social Sciences, 8(12), 2372-2378.

Copyright: (C) 2018 The Author(s)

Published by Human Resource Management Academic Research Society (www.hrmars.com)

This article is published under the Creative Commons Attribution (CC BY 4.0) license. Anyone may reproduce, distribute, translate and create derivative works of this article (for both commercial and non-commercial purposes), subject to full attribution to the original publication and authors. The full terms of this license may be seen at: http://creativecommons.org/licences/by/4.0/legalcode

Vol. 8, No. 12, 2018, Pg. 2372 - 2378

http://hrmars.com/index.php/pages/detail/IJARBSS

JOURNAL HOMEPAGE

Full Terms \& Conditions of access and use can be found at http://hrmars.com/index.php/pages/detail/publication-ethics 


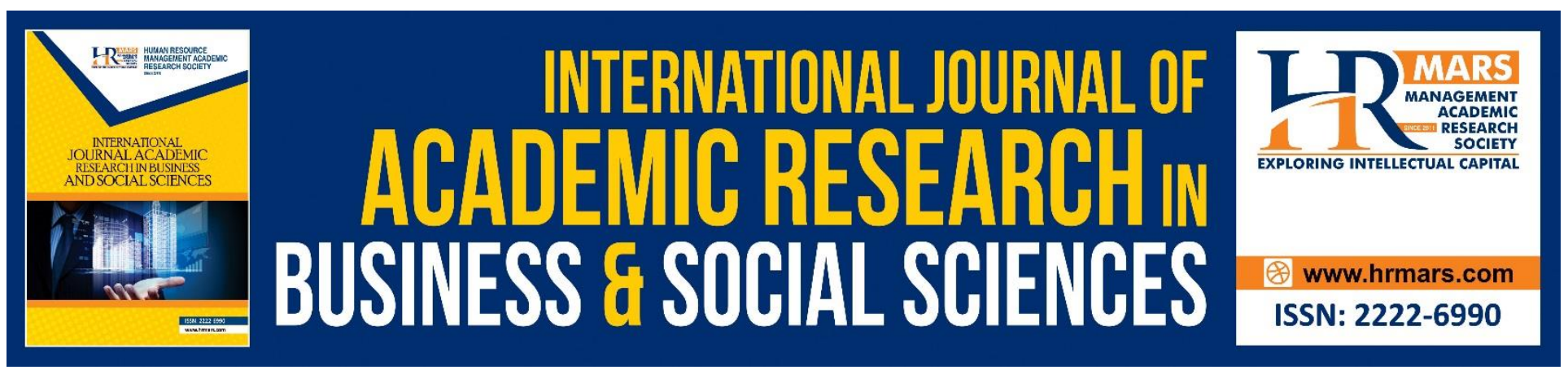

\title{
Smart Diagnostic Test in Remedial Education
}

\author{
Noor Aini Binti Ahmad \\ Universiti Pendidikan Sultan Idris, Malaysia
}

\begin{abstract}
Reading ability and reading efficiency is a basic necessity in the learning process. Children are encouraged to grow optimally so that they can master the language accordingly to their level of development. Among the factors contributing to the problem of children not being able to master reading skills at primary level is that they not yet ready to learn to read or they encounter difficulties in reading tasks. Intervention using multimedia software might help them in acquiring reading skills. Personal learning is a teaching and learning approach based on individual needs and interests. Basically, diagnostic tests are always associated with the level of reading ability of any children. This article discusses on smart diagnostics test and interventions for students who have not mastered reading skills. It is proposed that diagnostic tests be performed using voice recognition techniques where this technique facilitates teachers to administer the test in order to identify areas of strength and weaknesses of reading among children. Smart diagnostic test using voice recognition is proposed as an alternative way as it has impact on diagnostic tests to determine the level of reading ability of students.
\end{abstract}

Keywords: Diagnostic Test, Remedial Education, Voice Recognition

\section{Introduction}

Engaging and facilitating learning language skills via multimedia systems amongst at-risk students must be given attention by all parties to enable children to learn to read in a more organized and enjoyable manner. This can be full fill by using many multimedia tools that can be downloaded for free and easily use by children (Noor Aini Ahmad, Anis Fatima and Yasmin Jeffry, 2016). Many students with learning disabilities employed reading difficulties (Abosi, 2007). The implementation of response to intervention requires that interventions for struggling students be provided through general education prior to referral for special education (Wanzek \& Cavanaugh, 2012). Other than this, there are also children who need remedial education services.

Remedial education helps students with special needs learn basic skills (Chew, 2015). The Literacy and Numeracy Screening (LINUS) program is geared towards problematic students in mastering reading, writing and counting skills (Zinitulniza, 2011). The remedial program proved to be very effective for group of students with limited memory skills or skills involving memory (Toll and Luit, 2013). The remedial program trains them to manage time and learning materials, manage 
behavior towards learning activities, focusing on motivation and setting goals in education according to student's level of abilities. Remedial education is an initiative in helping low-achieving students to learn reading skills (Chen and $\mathrm{Yu}, 2016)$. The needs for low achievement pupils can be identified and fulfilled by providing appropriate teaching and learning materials according to their cognitive level (Siti Barokah, Hasnah and Anuar, 2012). Abdul Rashid and Rashidah (2012) found that teaching aids had a significant impact in improving the achievement of students' especially in reading skills. Thus, educators should always be prepare to help students to master reading skills. Among the priority aspect that can be look into is conducting preliminary detection tests such as diagnostic tests and intervention.

\section{Diagnostic and Intervention}

Early literacy skills should be addressed by parents and teachers (Dennis and Votteler, 2013). Writing and reading skills as well as intervention requirements to address them are also important (Mason, Davison, Hammer, Miller and Glutting, 2013). Certain inaccessible errors occur in almost all languages are confusion of similar shape letters. Some students have general disproportionate skills and have difficulty influencing the acquisition of reading skills, achieving a lower level of reading efficiency even though they are given normal education guidance (Zikl, Bartošová, Víšková, Havlíčková, Kučírková, Navrátilová and Zetková, (2015). Dyslexia for an example is associated with the difficulty of recognizing words and the ability to spell. This difficulty is usually due to the deficit in the language, phonology, problem in reading comprehension and the lack of reading experience inhibiting vocabulary growth (Soriano-Ferrer and Echegaray-Bengoa, 2014). The repeat reading method is one of the most frequently used method for improving reading ability. The repeat reading method involves reading the same text repeatedly until the student reaches the set of fluid level (Schumm, 2006).

Individuals who have problems mastering reading skills face (1) difficulty and perception errors (visual-spatial concepts in motor perception behavior, temporal concepts, perception of hearing perception, perceptual-motor errors and visual memory damage), (2) difficulty and psychomotor errors (difficulties in the acquisition and development of body schemes and spatial orientation in the acquisition and development of simplicity, while conducting basic motor behavior, conveying continuous, inversions in motor graphics schemes and lack of speed in motion) and (3) difficulty in reading (omission, replacement, spin, participation or translation, inspection or aggregate). Low reading levels are often associated with lack of understanding and phrase restriction in the texts (Colomino and Naranjo, (2014).

The current and previous research suggests that specific sight-word reading intervention and other applications of computer-based flash card interventions may prove useful to school psychologists who serve as consultants (Yaw, Skinner, Orsega, Parkhurst, Booher \& Chambers, 2012). Over the intervention period, improvements were made on measures of reading, phonological awareness and language skills. Although the intervention was effective, it should be noted that most children remained poor readers and require ongoing remediation (Duff, Fieldsend, Bowyer-Crane and Hulme, 2008).

Thus, the education world needs to be in line with the fast pace of technological progress. Remedial education also requires technology in identifying areas of strength and weakness of the 
INTERNATIONAL JOURNAL OF ACADEMIC RESEARCH IN BUSINESS AND SOCIAL SCIENCES

Vol. 8, No. 12, Dec, 2018, E-ISSN: 2222-6990 @ 2018 HRMARS

students and this can be done by conducting diagnostic tests and learning using technology. Diagnostic tests can also be performed using voice recognition techniques.

\section{Voice Recognition}

Voice recognition is the ability of a machine or program to identify words and phrases in speech language and convert them into machine readable formats. The basics of speech recognition software have limited vocabulary of words and can only identify if they speak clearly. Speech recognition applications include routing, speech-to-text, voice dialing and voice search applications. Speech recognition and voice recognition are sometimes used alternately, however it means different things.

Voice recognition is the most basic element while speech recognition is a result of voice recognition. Without voice recognition then speech recognition will not be born. In other word, speech recognition is a subset of voice recognition. However, the basic definition is still the same. Only speech captures sound that is classified as an expression while voice recognition captures whatever sound it produces.

Roskos and Brueck (2009) lists out the features of the system as well as the essential multimedia elements that must exist in system conceptualization. At the same time, they also examined on the benefits of integrating the multimedia elements in order to optimize the material to foster reading among students. Biancarosa and Griffiths (2012) discuss similar things but relate the existence of such features and multimedia elements to teaching types such as basic skill instruction, activation of self-readers and strategies, knowledge building and support to help read, individual support and assessment.

Mckenna and Zucker (2009) also focus on the use of electronic systems which explain that material selection for teaching purposes should be based on objective and purpose of reading and teaching reading skills. They add to the features of this system as balancing because students can utilize features such as voice text to hear a word or animation use to understand the context of the story. They propose the use of interactive-compensatory reading model as an applied model to examine the relationship between the system and the mastery of reading. Hence, voice recognition helps teachers perform preliminary detection of their pupils more accurately and effectively. Voice recognition techniques also save the administration time of diagnostic tests that are usually done manually.

Figure 1-3 show the interface of SOBI voice recognition whereby in the current research, a system to diagnose areas of weakness and strength of students in reading skills has been develop. As a start, five words from CVCV, CVCVCV, CVC and CVCVC word groups are selected. The current study also benefits the users through information sharing that can help them analyze and then evaluate the effectiveness of the practice that can be practiced at school. Directly, it is also expected to be able to enrich the diagnostic technique of pupils for initial intervention as the system is expected to facilitate teachers to conduct diagnostic tests more accurately and effectively. 
INTERNATIONAL JOURNAL OF ACADEMIC RESEARCH IN BUSINESS AND SOCIAL SCIENCES Vol. 8, No. 12, Dec, 2018, E-ISSN: 2222-6990 @ 2018 HRMARS
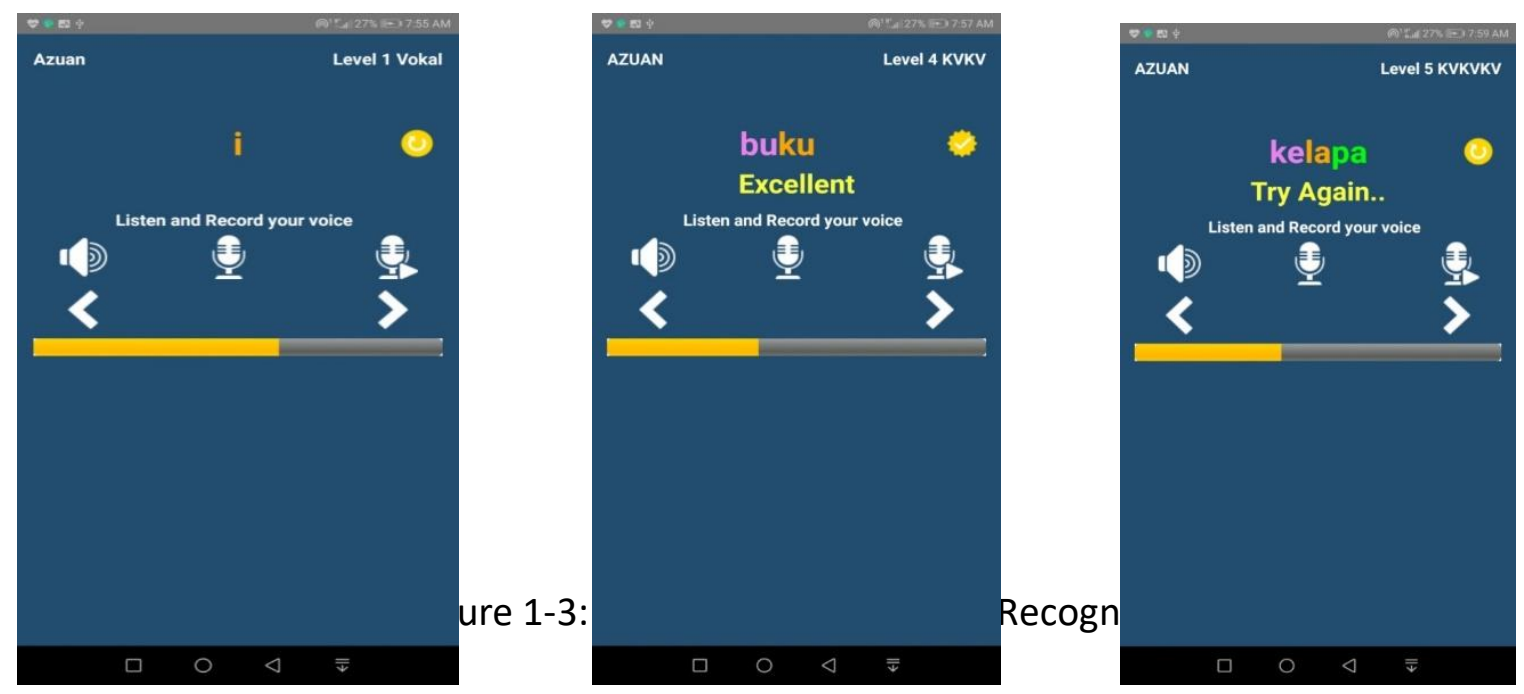

\section{CONCLUSION}

Each child has a unique individual profile, character, preferences, abilities and difficulties. Undoubtedly, they have their own potentials and strengths which must be broaden and improved efficiently. However, they have weaknesses in academic skills sometimes presented in reading or/and writing which are to be thoroughly developed via make use of various types of individualized intervention as well as provision of an effective teaching methods. It is quite clear that there must be a strategic goal for all of us as parents, academics, educational researchers and teachers to facilitate intervention in school. And most of the time, intervention starts with result from diagnostic test. Smart diagnostic test using voice recognition should be used as it provides a better platform in diagnosis that can be widely used in schools.

A prototype smart diagnostic test engines in this article is develop to identify areas of weakness or strength of students in reading skills. Voice recognition techniques in the application is use as a way of determining whether the detected pronunciation is correct or vice versa. As a recommendation, a prototype application of smart app search engine using voice recognition technique ought to be develop in order to diagnose students ability and to identify areas of their strengths and weaknesses in reading skills.

\section{Acknowledgement}

This work was supported by The Ministry of Higher Education, Universiti Putra Malaysia, Universiti Pendidikan Sultan Idris (UPSI), the Research Management and Innovation Centre of UPSI and the Faculty of Education and Human Development, UPSI.

[RACE: 2016-0001-107-62]. 


\section{Corresponding Author}

Noor Aini Ahmad

Special Education Department

Faculty of Human Development

Universiti Pendidikan Sultan Idris,

35900 Tanjong Malim

Perak, Malaysia

Email: noor.aini@fpm.upsi.edu.my

\section{References}

Jamian, A. R. \& Baharom, R. (2012). The Application of Teaching Aids and School Supportive Factors in Learning Reading Skill among the Remedial Students in Under Enrolment Schools. Social and Behavioral Sciences, 35, 187-194.

Abosi, O. (2007). Educating Children with Learning Disabilities in Africa. Learning Disabilities Research \& Practice, 22(3): 196-201.

Biancarosa, G. dan Griffiths, G.G. (2012). Technology tools to support reading in the digital age. The Future of Children, 22(2), 138-160

Chen, H. S., \& Yu, P. (2016). Closing achievement gaps and beyond: teachers' reactions to the remedial education policy in Taiwan. Asia Pacific Education Rev, 17, 609-624.

Chew, F. P. (2015). Pelaksanaan program literasi dan numerasi di sekolah rendah. Jurnal Pendidikan Bahasa Melayu, 5(2), 1-11.

Colomino, N. C. \& Naranjo, F. J. R. (2014). Body Percussion and Dyslexia. Theoretical And Practical Contribution Through The BAPNE Method. Procedia-Social and Behavioral Sciences, 132, 686690.

Dennis, L.R., \& Votteler, N. K. (2013). Preschool Teachers and Children's Emergent Writing: Supporting Diverse Learners. Early Childhood Education Journal, 41, 439-446.

Duff, F, J., Fieldsend, E., Bowyer-Crane, C. \& Hulme, C. (2008). Reading with vocabulary intervention: Evaluation of a $\mathrm{n}$ instruction for children with poor response to reading intervention. Thinking Skills and Creativity, 31: 319-336.

Liu, Q., Diao, L., \& Tu, G. (2010). The application of artificial intelligence in mobile learning. International Conference on System Science, Engineering Design and Manufacturing Information Proceeding: 80-83.

Mason, L. H., Davison, M. D., Hammer, C. S., Miller, C. A., \& Glutting, J. J. (2013). Knowledge, writing, and language outcomes for a reading comprehension and writing intervention. Reading Writing, 26, 1133-1158.

McKenna, M.C dan Zucker, T.A. (2009). Use of electronic storybooks in reading insruction. In Bus, A. G. Multimedia and literacy development: improving achievement for young learners. New York: Routledge.

Ahmad, N. A., Savugathali, A. F. \& Jeffry, Y. (2016). Engaging and facilitating learning language skills via multimedia systems amongst at-risk students. Journal of Teaching and Education, 5(02): 87-94.

Roskos, K. dan Brueck, J. (2009). The eBook as a learning object in an online world. In Bus, A. G. 
Multimedia and literacy development: Improving achievement for young learners. New York: Routledge.

Schumm, J. S. (2006). Reading Assessment and Instruction for All Learners. New York: Guilford Press.

Soriano-Ferrer, M. \& Echegaray-Bengoa, J. A. (2014). A Scale of Knowledge and Beliefs about Developmental Dyslexia: Scale Development and Validation. Procedia-Social and Behavioral Sciences, 132, 203-208.

Toll, S. W. M., \& Luit, J. E. H. V. (2013). Accelerating the early numeracy development of kindergartners with limited working memory skills through remedial education. Research in Developmental Disabilities, 34, 745-755.

Wanzek, J., \& Cavanaugh, C. (2012). Characteristics of general education reading interventions implemented in elementary schools for students with reading difficulties. Remedial and Special Education, 33 (1): 192-202.

Yaw, J., Skinner, C. H., Orsega, M.C., Parkhurst, J., Booher, J., \& Chambers, K. (2012). Evaluating a computer-based sight-word reading intervention in a student with intellectual disabilities. Journal of Applied School Psychology, 28, 354-366.

Zikl, P., Bartosova, I. V., Viskova, K. J., Havlickova, K., Kucirkova, A., Navratilova, J., \& Zetkova, B. (2015). The possibilities of ICT use for compensation of difficulties with reading in pupils with dyslexia. Social and Behavioral Sciences, 176, $915-922$.

Kadir, Z. A. (2011). Sudut Pandang Muhyiddin Yassin. Institut Terjemahan Negara Malaysia: Kuala Lumpur. 